\title{
Comparative Linear Craniofacial Anthropometric Profile of the Igbo, Ijaw and Yoruba of Southern Nigeria
}

\author{
Okoh $\mathrm{PD}^{1 *}$, Fawehinmi HB ${ }^{2}$
}

${ }_{1}^{1}$ Department of Surgery, Faculty of Clinical Sciences, University of Port Harcourt Teaching Hospital, Port Harcourt, Nigeria
${ }^{2}$ Department of Anatomy, Faculty of Basic Medical Sciences, University of Port Harcourt, Port Harcourt, Nigeria

DOI: $10.36347 /$ simcr.2020.v08i03.006

| Received: 19.02.2020 | Accepted: 26.02.2020 | Published: 07.03.2020

*Corresponding author: Okoh PD

Abstract

Original Research Article

Craniofacial analysis of soft tissues using photographs provides information about the normative values of various facial parameters of a given ethnic group or race. It could also aid diagnosis of any form of deviation or abnormalities as well as help in the design of treatment plan for orthodontic, maxillofacial or facial plastic surgery. The aim of the study was to compare some linear facial parameters of adult male Igbo, Ijaw and Yoruba of southern Nigeria using photogrammetry and to compare the mean values of each of the parameters of these negroid populations with those of other races. The study made use of a total number of one thousand two hundred (1200) subjects with four hundred (400) drawn from each of the Igbo, Yoruba and Ijaw ethnic groups whose ages ranged from 21 to 40 years. Determination of minimum sample size was done using the Taro-Yamane's formula. The study employed the use of standardized photographic record of the 1200 adults taken in the natural head position. Photographs were analysed using a software tool (WinImager). Statistical analysis was done using SPSS version 25.0 and Microsoft Excel 2019. Results showed ethnic variations across the different ethnic groups. Age related changes were also observed. On comparison to other races, noticeable differences were observed which underscores racial variation. These values describe the norm and anthropometric position of southern Nigeria among other races. This could be use in medicine, anthropometric studies and forensics.

Keywords: Comparative, linear, craniofacial, anthropometric, southern Nigeria.

Copyright @ 2020: This is an open-access article distributed under the terms of the Creative Commons Attribution license which permits unrestricted use, distribution, and reproduction in any medium for non-commercial use (NonCommercial, or CC-BY-NC) provided the original author and source are credited.

\section{INTRODUCTION}

Southern part of Nigeria also known as southern Nigeria is the southern protectorate of Nigeria comprising so many ethnic groups majority among which are the Igbo, Ijaw and Yoruba. The Igbo and Yoruba are among the three major ethnic groups in Nigeria. The Igbo are found mainly in southeastern and midwestern (Delta State) of Nigeria. They are also found in other African countries [1,2] and outside Africa. They are one of the largest ethnic groups in Africa [3]. The Ijaw are found in riverine locations near many sea trade routes [4] in the southernmost part of Nigeria. The Yoruba are predominantly found in southwestern Nigeria. They make up to about $21 \%$ of Nigeria's population [5].

The face gives recognition to an individual, and this makes one different from the others. The individuality of the face results primarily from anatomical variation: variations in the shape and relative prominence of the features of the underlying cranium; in the deposition of fatty tissue; in the color and effects of aging on the overlying skin; and in the abundance, nature, and placement of hair on the face and scalp [6]. Although the face identifies an individual, certain variations that distinguish different groups of people exist. Traits that give rise to these variations are largely influenced by factors such as race, ethnicity, age, sex, culture, etc[7, 8]. Furthermore, features of different races and ethnic groups are not randomly distributed, but appear in geographical clusters [9]. Also, soft tissues covering the bones and teeth may differ so greatly that dentoskeletal pattern may be insufficient to guide formulation of treatment plan [1012]. It is therefore inappropriate to apply the norms for one race to a different race. The most common means of surgical and forensic facial comparison is by photographic identification. Researchers and clinicians have used photographs to undertake analysis of facial morphology by identifying certain landmarks on various facial structures and extracting measurements such as distances, angles, and ratios. Norms for 
different ethnic groups can differ widely therefore, the need to undertake this study.

Studies have been done on linear facial parameters using manual anthropometry. The aim of this study therefore was to document and compare the linear craniofacial norms of the Igbo, Ijaw and Yoruba of southern Nigeria using photogrammetry.

\section{Materials ANd Methods}

The research design was a cross-sectional design which determined the photogrammetric features of three southern Nigerian ethnic groups.

The population for the study included participants drawn from locations in Yenegoa, Amassoma, Ogbia, Kaima and Igbogene in Bayelsa State, Owerri, Mbaitoli, Ngor-Okpala, Orlu, Mbaise and Okigwe in Imo State; Akure, Idanre, Akoko and Okitipupa in Ondo State constituted the study areas representing the Igbo, Ijaw and Yoruba areas respectively.

The sampling technique was multistage random sampling. Subjects were randomly selected from amongst adult males from the 3 major tribes (Yoruba, Ijaw and Igbo) residing in Imo, Ondo and Bayelsa states all in southern Nigeria. Determination of minimum sample size was done using the TaroYamane's formula. A total number of one thousand two hundred (1200) subjects with four hundred (400) drawn from each of the Igbo Yoruba and Ijaw ethnic groups whose ages ranged from 21 to 40 years were used. Minimum sample size for the study was determined using the Taro-Yamane formula, $n=N / \llbracket 1+N(e)^{2} \rrbracket$ where $\mathrm{n}=$ minimum sample size, $\mathrm{N}=$ total population and $\mathrm{e}=$ margin of error $=0.05$.

Only Adult males between the ages of 21 and 40 years were included in this research. It was ascertained that recruited subjects have both parents and four grand parents from the same ethnic group and had no previous history of orthodontic or surgical treatment. This was determined through questionnaires.

The photogrammetric method involved direct capturing of photographic images of the face taken from a digital camera (Nikon COOLPIX S2800) under illumination and analysis of the photographs using facial parameters derived from standard anatomical landmarks. The photographic set-up was made for capture in the natural head position (NHP), with a minimum resolution of $640 \times 480$ pixel. The set-up was done with a tripod (WT 3570) for supporting the digital camera. Adjustment of the tripod enabled the optical axis of the lens that was kept in a horizontal position during the recording, adapted to each subjects' body height in a standing position. Each subject was made to be relaxed with both the arms hanging freely on each side of the trunk. The camera to the subject distance was maintained at a constant distance of $1.0-1.5$ meters for all the subjects. The subject was asked to look at an object at his eye level. Then the subject was asked to keep the lips in relaxed position so that the right-side profile record was taken in Natural Head Position (NHP). Some landmarks were used to obtain the parameters (as shown in figures 1 and 2).

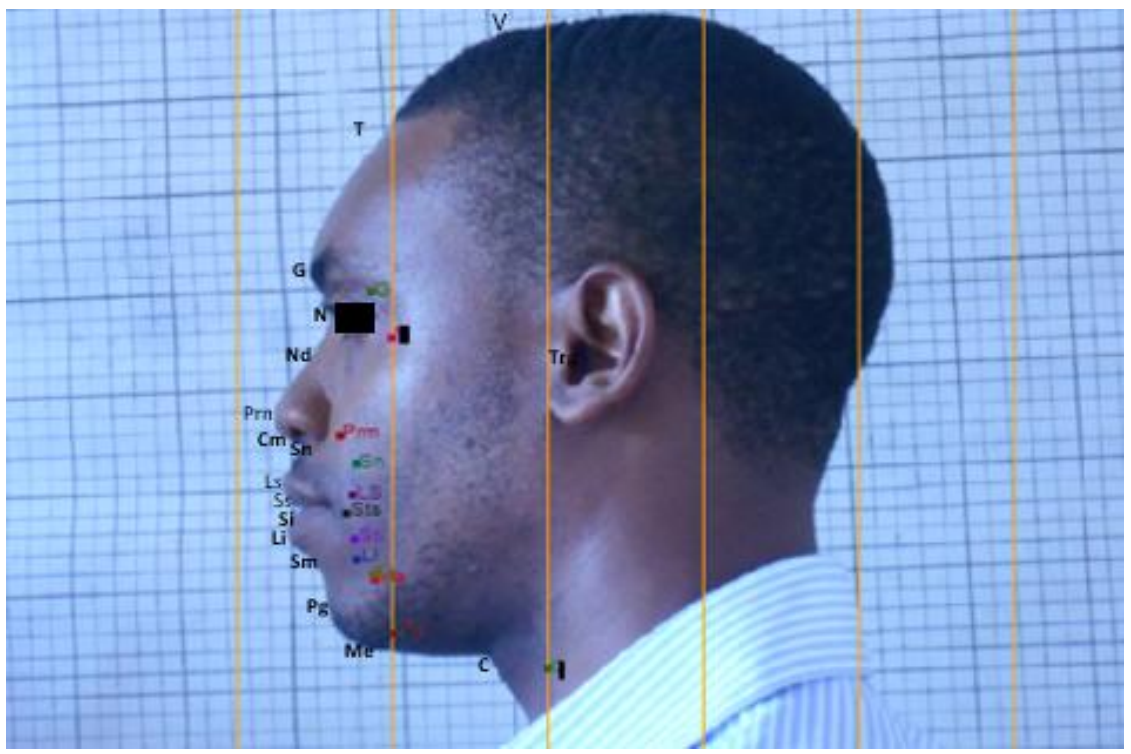

Fig-1: Soft-tissue points: vertex (V), trichion (T), glabella (G), nasion (N), nasal dorsum (Nd), tragion (Trg), pronasal (Prn), columella (Cm), subnasal (Sn), labial superior (Ls), stomion superior (Ss), stomion inferior (Si), labial inferior, supramentale (Sm), pogonion (Pg), menton (Me), cervical point $(C)$ 


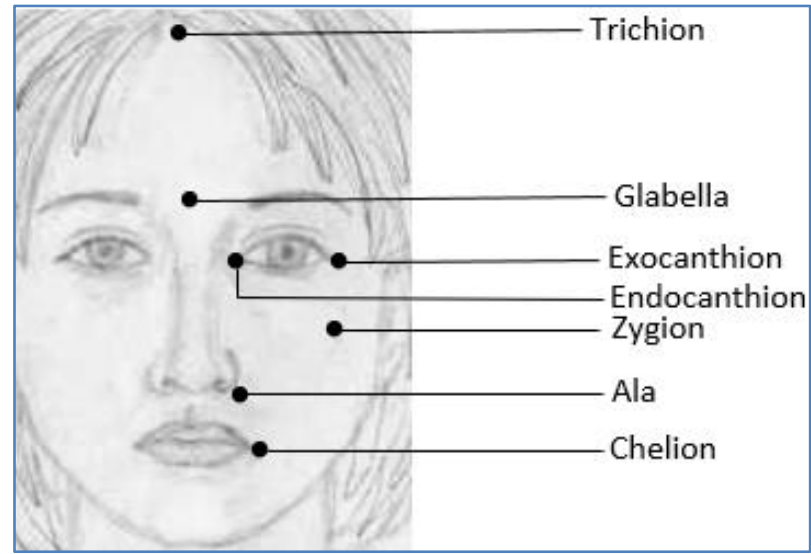

Fig-2: Some soft tissue landmarks (anterior view)

With the identified landmarks, the following parameters were measured:

Total Anterior Facial Height (N-me): Nasion to menton.

Special Head Height (V-En): Vertex to endocanthion

Special Face Height (En-Gn): Endocanthion to menton

Forehead Height II (Tr-N): Trichion to nasion

Nose Length (n-prn): Nasion to pronasale

Lower Face Height (Sn-Me): Subnasale to menton

Forehead Height I (Tr-G): Trichion to glabella

Special Upper Face Height 1 (G-Sn): Glabella to subnasale

Ear Length (Spu-Sbu): Superaurale to subaurale

Intercanthal Distance (En-En): Distance in between left and right endocanthion
Outer Canthal Distance (Exr-Exl): Distance between the left and right exocanthion

Nasal Width (Al-Al): Distance in between the left and right alar

Nasal Tip Projection Line (Sn-Prn): Horizontal distance in between the mid facial vertical line and pronasale

Eye Fissure Width (ex-en): Distance in between the exocanthion and endocanthion

Mouth Width (Chr-Chl): Distance between the right and left chellion.

Height of Calvaria (v-tr): Vertex to trichion

Lower Nasal (Mn-Sn): Mid nasal to subnasale.

Upper Nasal Height (N-Mn): Nasion to mid-nasal

Facial Width (Zy-Zy): Zygion to zygion.

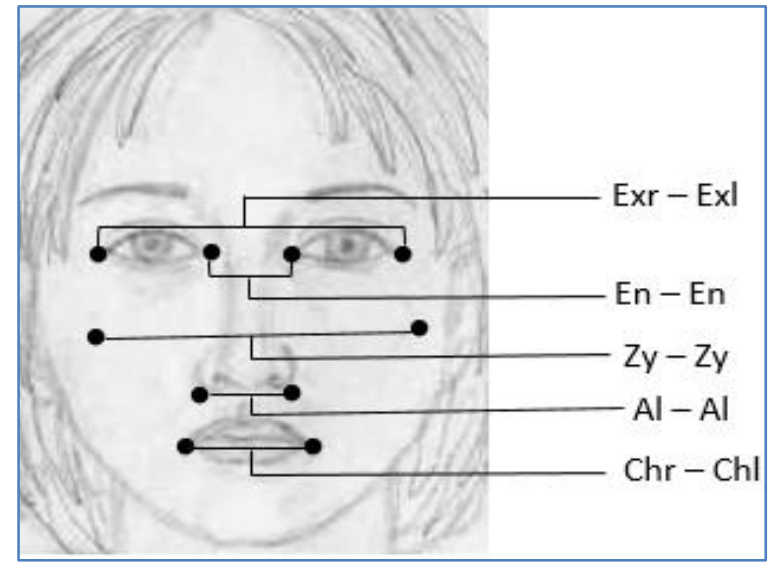

Fig-3: Illustration of some linear (horizontal) parameters; Exr - Exl (outer canthal distance), En - En (inner canthal distance); Zy - Zy (facial width), Al - Al (nose width), Chr Chl (mouth width)

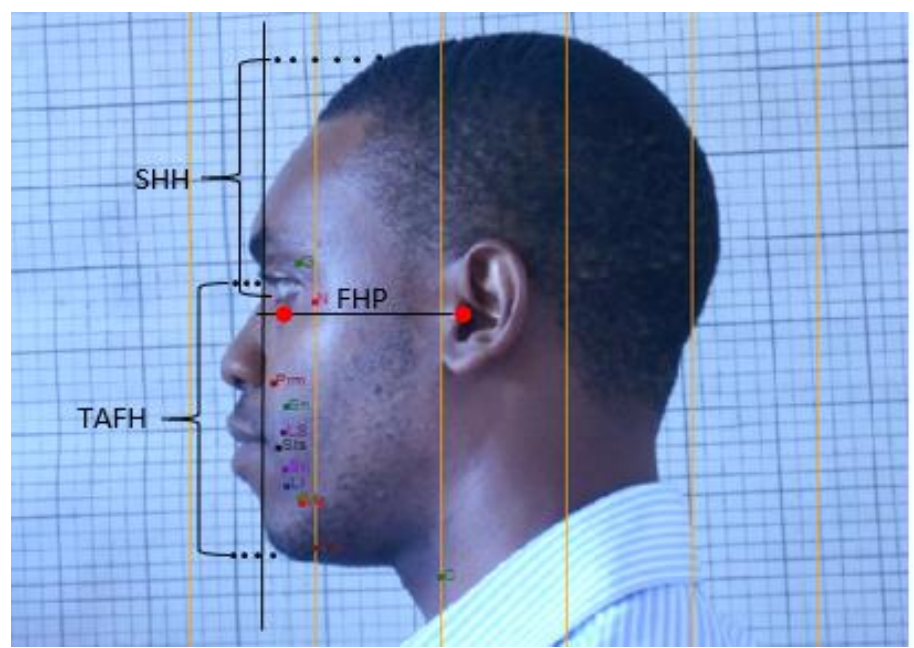

Fig-4: Some linear (vertical) parameters; TAFH (total anterior facial height), SHH (special head height) 


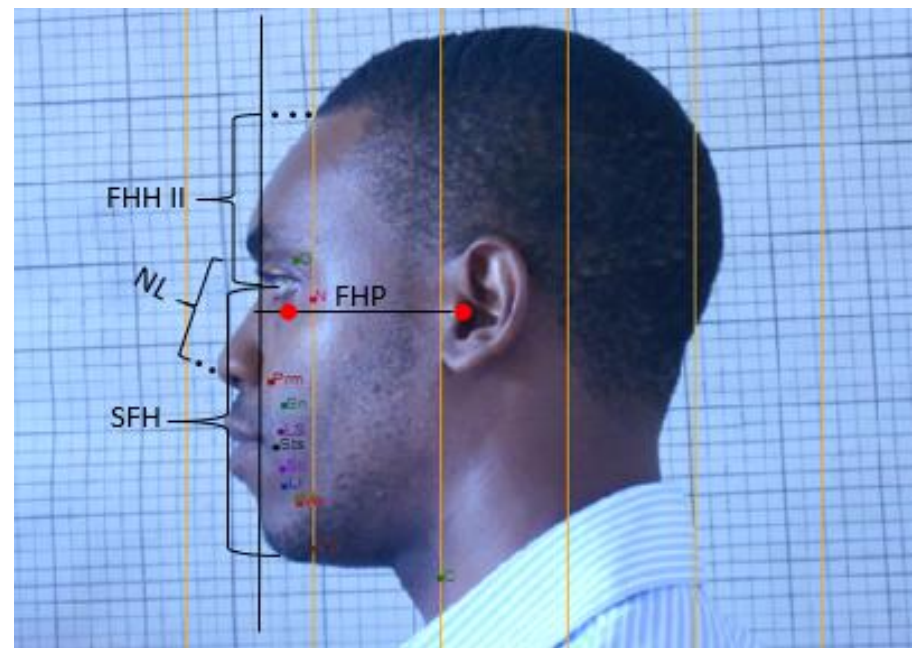

Fig-5A: Some linear (vertical) parameters; FHH II (forehead height II), NL (n-prn) (nasal length), SFH (special face height)

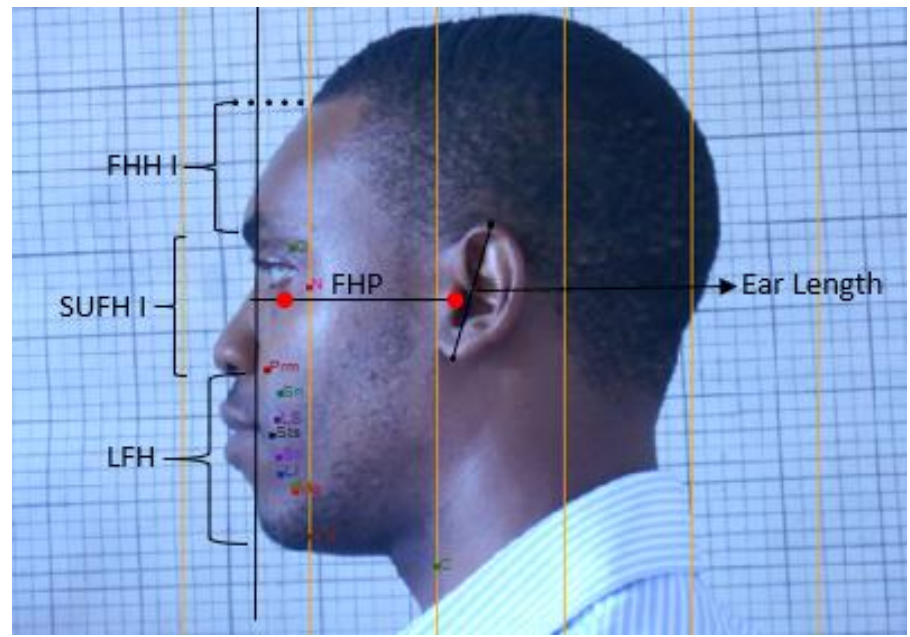

Fig-5B: FHH I (forehead height I), SUFH I (special upper face height I), LFH (lower face height)

\section{Statistical Analysis}

Statistical analysis was done using statistical package for the social science (SPSS version 25.0) and Microsoft Excel 2019. Continuous variables were presented as mean $\pm \mathrm{SD}$; minimum and maximum. Analysis of variance (ANOVA) was done to establish significant differences in the measured anthropometric parameters according to ethnic group. Age was divided into two groups, $21-30$ and $31-40$ years. Independent sample t-test was therefore carried out to determine significant difference in the measured anthropometric parameters according to age. The confidence interval was set at $95 \%$, therefore $p<0.05$ was considered significant.

\section{RESULTS}

Results are shown in tables $1-3$. Table 1 shows descriptive statistics of the measured linear craniofacial parameters of the three southern Nigerian ethnic groups, the respective mean of each group and the total mean of the three ethnic groups. Total Anterior Facial Height (TAFH) was found to be highest in Yorubas and least in the Ijaw whereas Special Head Height (SHH) was highest in the Igbos and least in the
Ijaws. Special Face Height (SFH) was highest in Yorubas and least in the Igbos. Nose Length (NL) was found to be highest among the Yoruba and least among the Igbo while Lower Face Height (LFH) was highest among the Igbo and least in the Ijaw. The mean Forehead Height I (FH I) was highest in the Yoruba and least in the Igbo. The mean Forehead Height II (FH II) was highest in the Igbo and least in the Ijaw. Special Upper Face Height I (SUFH I) was highest among the Yoruba and least among the Igbo. Ear Length (EL) was highest in the Yoruba and least in the Igbo. Intercanthal Distance (ICD) was found to be highest in the Yoruba and least in the Igbo. Mean Outer Canthal Distance (OCD) was highest in Yorubas and least among the Igbo. Nasal Width (NW) was highest among the Yoruba and least among the Igbo. Mean Nasal Tip Projection (NTP) for the Igbo was highest in the Igbo and least among the Yoruba. Mean Eye Fissure Width (EFW) was highest in the Yoruba and least among the Igbo. Mean Mouth Width (MW) for the Igbo was least in the Igbo and highest in the Yoruba. Mean Height of Calvaria (HOC) was least in the Igbo and highest in the Yoruba. Mean Lower Nasal (LNH) was found to be highest in the Igbo and least in the Yoruba. Facial Width (FW) was found to highest in the Yoruba and 
least in the Igbo (table 1). On comparison among the three ethnic groups, ANOVA revealed that Special Face Height (SFH), Lower Face Height (LFH), Forehead Height I (FHH I), Intercanthal Distance (ICD), Outer Canthal Distance (OCD), Mouth Width (MW), Upper Nasal Height (UNH) and Facial Width (FW) were statistically significant with $\rho$-values 0.00 and 0.01 respectively (table 2); other linear parameters were not statistically significant $(\rho>0.05)$. When compared among age groups, independent sample t-test showed that Special Face Height (SFH), Forehead Height II (FHH II), Nasal Tip Projection (NTP), Mouth Width (MW) and Upper Nasal Height (UNH) were statistically significant $(\rho<0.05)$ (table 3$)$; other parameters showed no statistically significance $(\rho>0.05)$.

Table-1: Descriptive statistics of the measured Linear Craniofacial Parameters of the Igbo, Ijaw and Yoruba ethnic groups (mm)

\begin{tabular}{|c|c|c|c|c|c|c|c|c|c|c|c|c|}
\hline \multirow{2}{*}{$\begin{array}{c}\text { Linear } \\
\text { Craniofacial } \\
\text { Parameters }\end{array}$} & \multicolumn{3}{|c|}{ IGBO } & \multicolumn{3}{|c|}{ IJAW } & \multicolumn{3}{|c|}{ YORUBA } & \multicolumn{3}{|c|}{ ALL } \\
\hline & $\begin{array}{c}\text { Mean } \pm \\
\text { SD }\end{array}$ & Min & Max & $\begin{array}{c}\text { Mean } \pm \\
\text { SD }\end{array}$ & Min & Max & $\begin{array}{c}\text { Mean } \pm \\
\text { SD }\end{array}$ & Min & Max & $\begin{array}{c}\text { Mean } \pm \\
\text { SD }\end{array}$ & Min & $\operatorname{Max}$ \\
\hline TAFH & $124.37 \pm 3.12$ & 119.82 & 131.70 & $123.83 \pm 3.46$ & 118.87 & 131.70 & $123.96 \pm 3.30$ & 119.74 & 131.70 & $124.06 \pm 3.30$ & 118.87 & 131.70 \\
\hline $\mathrm{SHH}$ & $112.39 \pm 3.86$ & 105.90 & 119.30 & $110.39 \pm 3.86$ & 104.90 & 118.10 & $111.98 \pm 3.77$ & 105.26 & 118.10 & $112.09 \pm 3.77$ & 104.90 & 119.30 \\
\hline SFH & $104.44 \pm 2.38$ & 101.90 & 110.82 & $106.97 \pm 3.72$ & 100.90 & 112.39 & $107.59 \pm 2.32$ & 101.61 & 111.90 & $106.33 \pm 3.10$ & 100.90 & 112.39 \\
\hline NL & $47.94 \pm 2.08$ & 40.21 & 49.84 & $46.08 \pm 2.13$ & 41.12 & 50.50 & $45.82 \pm 1.98$ & 40.21 & 49.84 & $46.61 \pm 2.06$ & 40.21 & 50.50 \\
\hline LFH & $67.45 \pm 2.47$ & 61.00 & 72.98 & $65.93 \pm 2.79$ & 61.00 & 73.59 & $66.70 \pm 2.46$ & 61.00 & 72.98 & $66.02 \pm 2.59$ & 61.00 & 73.59 \\
\hline FH I & $56.70 \pm 3.40$ & 48.15 & 63.22 & $57.25 \pm 3.19$ & 48.15 & 63.90 & $58.41 \pm 3.41$ & 48.15 & 63.22 & $57.79 \pm 3.35$ & 48.15 & 63.90 \\
\hline FH II & $68.45 \pm 3.62$ & 64.52 & 73.90 & $68.25 \pm 3.41$ & 63.90 & 72.90 & $68.36 \pm 3.83$ & 64.52 & 73.70 & $68.36 \pm 3.62$ & 63.90 & 73.90 \\
\hline SUFH I & $64.20 \pm 2.35$ & 48.15 & 70.80 & $65.06 \pm 2.14$ & 48.15 & 69.96 & $66.99 \pm 2.24$ & 48.15 & 70.57 & $65.08 \pm 2.25$ & 48.15 & 70.80 \\
\hline EL & $55.30 \pm 2.18$ & 51.14 & 62.99 & $57.04 \pm 2.49$ & 49.50 & 63.50 & $59.96 \pm 2.40$ & 49.50 & 62.87 & $57.10 \pm 2.37$ & 49.50 & 63.50 \\
\hline ICD & $33.40 \pm 2.89$ & 31.33 & 49.20 & $35.86 \pm 3.36$ & 29.30 & 41.20 & $38.51 \pm 3.48$ & 29.30 & 40.89 & $35.92 \pm 3.82$ & 29.30 & 49.20 \\
\hline OCD & $103.22 \pm 3.58$ & 98.75 & 113.20 & $104.34 \pm 3.41$ & 98.50 & 113.20 & $105.60 \pm 3.06$ & 98.75 & 113.20 & $105.05 \pm 3.37$ & 98.50 & 113.20 \\
\hline NW & $38.91 \pm 2.63$ & 33.88 & 49.20 & $39.86 \pm 2.39$ & 34.40 & 49.20 & $41.53 \pm 2.48$ & 33.88 & 49.20 & $40.76 \pm 2.51$ & 33.88 & 49.20 \\
\hline NTP & $13.96 \pm 1.96$ & 9.68 & 17.56 & $12.05 \pm 2.13$ & 8.90 & 17.56 & $11.91 \pm 2.00$ & 9.68 & 17.56 & $12.98 \pm 2.03$ & 8.90 & 17.56 \\
\hline EFW & $30.73 \pm 1.29$ & 27.60 & 34.35 & $32.85 \pm 1.38$ & 26.80 & 35.20 & $33.64 \pm 1.25$ & 27.60 & 34.35 & $32.74 \pm 1.31$ & 26.80 & 35.20 \\
\hline MW & $52.41 \pm 1.84$ & 47.80 & 57.80 & $53.24 \pm 1.71$ & 46.89 & 57.00 & $54.20 \pm 1.77$ & 47.90 & 57.80 & $53.95 \pm 1.81$ & 46.89 & 57.80 \\
\hline $\mathrm{HOC}$ & $37.57 \pm 2.61$ & 33.16 & 49.20 & $38.51 \pm 2.57$ & 33.80 & 49.20 & $40.37 \pm 2.63$ & 33.16 & 49.20 & $38.49 \pm 2.60$ & 33.16 & 49.20 \\
\hline LNH & $13.43 \pm 1.99$ & 6.00 & 15.77 & $12.55 \pm 1.99$ & 6.00 & 15.20 & $11.34 \pm 1.93$ & 6.00 & 14.90 & $12.44 \pm 1.97$ & 6.00 & 15.77 \\
\hline UNH & $46.90 \pm 2.46$ & 41.00 & 50.90 & $45.35 \pm 2.02$ & 41.00 & 51.20 & $44.22 \pm 2.21$ & 41.00 & 50.90 & $45.49 \pm 2.25$ & 41.00 & 51.20 \\
\hline FW & $131.55 \pm 2.51$ & 129.10 & 138.97 & $133.16 \pm 2.37$ & 128.80 & 138.90 & $134.06 \pm 2.54$ & 129.10 & 138.97 & $132.26 \pm 2.48$ & 128.80 & 138.97 \\
\hline
\end{tabular}

TAFH = Total Anterior Facial Height, SHH = Special Head Height, SFH = Special Face Height, NL = Nose Length, LFH = Lower Face Height, FH I = Forehead Height I, FH II = Forehead Height II, SUFH I = Special Upper Face Height I, EA = Ear Length, ICD = Intercanthal Distance, OCD = Outer canthal Distance, NW = Nasal Width, NTP = Nasal Tip Projection, EFW = Eye Fissure Width, MW = Mouth Width, HOC $=$ Height of Calvaria, LNH $=$ Lower Nasal Height, UNH = Upper Nasal Height, FW = Facial Width, SD = Standard Deviation, Min $=$ Minimum, Max $=$ Maximum

Table-2: Linear Craniofacial Parameters compared according to ethnic group using ANOVA

\begin{tabular}{|l|c|c|c|c|c|c|}
\hline $\begin{array}{l}\text { Linear Craniofacial } \\
\text { Parameters }\end{array}$ & $\begin{array}{c}\text { Sum of } \\
\text { Squares }\end{array}$ & $\begin{array}{c}\text { Mean } \\
\text { Square }\end{array}$ & Df & $\boldsymbol{F}$-value & $\boldsymbol{p}$-value & Inference \\
\hline Total Anterior Facial Height & 62.45 & 31.23 & 2 & 2.87 & 0.06 & NS \\
\hline Special Head Height & 55.55 & 27.78 & 2 & 1.95 & 0.14 & NS \\
\hline Special Face Height & 1614.19 & 807.10 & 2 & 97.32 & 0.00 & S \\
\hline Nose Length & 14.20 & 7.10 & 2 & 1.67 & 0.19 & NS \\
\hline Lower Face Height & 118.05 & 59.02 & 2 & 8.90 & 0.00 & S \\
\hline Forehead Height I & 146.92 & 73.46 & 2 & 6.61 & 0.00 & S \\
\hline Forehead Height II & 7.84 & 3.92 & 2 & 0.30 & 0.74 & NS \\
\hline Special Upper Face Height I & 8.84 & 4.42 & 2 & 0.88 & 0.42 & NS \\
\hline Ear Length & 25.61 & 12.81 & 2 & 2.29 & 0.10 & NS \\
\hline Inter Canthal Distance & 4787.39 & 2393.69 & 2 & 226.09 & 0.00 & S \\
\hline Outer Canthal Distance & 127.85 & 63.93 & 2 & 5.67 & 0.00 & S \\
\hline Nasal Width & 33.64 & 16.82 & 2 & 2.68 & 0.07 & NS \\
\hline Nasal Tip Projection & 4.02 & 2.01 & 2 & 0.49 & 0.61 & NS \\
\hline Eye Fissure Width & 8.91 & 4.45 & 2 & 2.61 & 0.07 & NS \\
\hline Mouth Width & 176.88 & 88.44 & 2 & 28.19 & 0.00 & S \\
\hline Height of Calvaria & 8.48 & 4.24 & 2 & 0.63 & 0.54 & NS \\
\hline Lower Nasal & 8.63 & 4.32 & 2 & 1.11 & 0.33 & NS \\
\hline Upper Nasal Height & 104.50 & 52.25 & 2 & 10.45 & 0.00 & S \\
\hline Facial Width & 53.82 & 26.91 & 2 & 4.41 & 0.01 & S \\
\hline
\end{tabular}


Okoh PD \& Fawehinmi HB, Sch J Med Case Rep, March., 2020; 8(3): 285-291

Table-3: Descriptive statistics of the measured linear craniofacial parameters according to age in all Subjects

\begin{tabular}{|c|c|c|c|c|c|c|c|c|}
\hline \multirow[t]{2}{*}{ Linear Craniofacial Parameters } & \multirow[t]{2}{*}{ Age group } & \multirow[t]{2}{*}{$\mathbf{N}$} & \multirow[t]{2}{*}{ Mean } & \multirow[t]{2}{*}{ SD } & \multicolumn{4}{|c|}{$t$-test } \\
\hline & & & & & Df & $t$-value & $p$-value & Inference \\
\hline \multirow[t]{2}{*}{ Total Anterior Facial Height } & $21-30$ & 985 & 124.02 & 3.31 & \multirow[t]{2}{*}{1198.00} & \multirow[t]{2}{*}{-0.89} & \multirow[t]{2}{*}{0.37} & \multirow[t]{2}{*}{$\mathrm{NS}$} \\
\hline & $31-40$ & 215 & 124.24 & 3.27 & & & & \\
\hline \multirow[t]{2}{*}{ Special Head Height } & $21-30$ & 985 & 112.06 & 3.76 & \multirow[t]{2}{*}{1198.00} & \multirow[t]{2}{*}{-0.67} & \multirow[t]{2}{*}{0.50} & \multirow[t]{2}{*}{ NS } \\
\hline & $31-40$ & 215 & 112.25 & 3.82 & & & & \\
\hline \multirow[t]{2}{*}{ Special Face Height } & $21-30$ & 985 & 105.24 & 3.01 & \multirow[t]{2}{*}{288.32} & \multirow[t]{2}{*}{-2.13} & \multirow[t]{2}{*}{0.03} & \multirow[t]{2}{*}{$\mathbf{S}$} \\
\hline & $31-40$ & 215 & 105.78 & 3.47 & & & & \\
\hline \multirow[t]{2}{*}{ Nose Length } & $21-30$ & 985 & 45.96 & 2.03 & \multirow[t]{2}{*}{1198.00} & \multirow[t]{2}{*}{0.54} & \multirow[t]{2}{*}{0.59} & NS \\
\hline & $31-40$ & 215 & 45.88 & 2.20 & & & & \\
\hline Lower Face Height & $21-30$ & 985 & 67.09 & 2.59 & 1198.00 & 1.91 & 0.06 & NS \\
\hline & $31-40$ & 215 & 66.72 & 2.57 & & & & \\
\hline Forehead Height I & $21-30$ & 985 & 56.81 & 3.33 & 1198.00 & 0.54 & 0.59 & NS \\
\hline & $31-40$ & 215 & 56.67 & 3.46 & & & & \\
\hline Forehead Height II & $21-30$ & 985 & 68.50 & 3.64 & 325.24 & 3.07 & 0.00 & $\mathbf{S}$ \\
\hline & $31-40$ & 215 & 67.69 & 3.47 & & & & \\
\hline Special Upper Face Height I & $21-30$ & 985 & 64.13 & 2.17 & 1198.00 & 1.53 & 0.13 & NS \\
\hline & $31-40$ & 215 & 63.87 & 2.55 & & & & \\
\hline Ear Length & $21-30$ & 985 & 56.04 & 2.41 & 1198.00 & -1.78 & 0.08 & NS \\
\hline & $31-40$ & 215 & 56.36 & 2.16 & & & & \\
\hline Intercanthal Distance & $21-30$ & 985 & 35.87 & 3.81 & 1198.00 & -0.97 & 0.33 & NS \\
\hline & $31-40$ & 215 & 36.15 & 3.86 & & & & \\
\hline Outer canthal Distance & $21-30$ & 985 & 103.97 & 3.35 & 1198.00 & -1.80 & 0.07 & NS \\
\hline & $31-40$ & 215 & 104.43 & 3.43 & & & & \\
\hline Nasal Width & $21-30$ & 985 & 38.81 & 2.52 & 1198.00 & 1.38 & 0.17 & NS \\
\hline & $31-40$ & 215 & 38.55 & 2.42 & & & & \\
\hline Nasal Tip Projection & $21-30$ & 985 & 12.91 & 2.04 & 1198.00 & -2.42 & 0.02 & $\mathbf{S}$ \\
\hline & $31-40$ & 215 & 13.28 & 1.98 & & & & \\
\hline Eye Fissure Width & $21-30$ & 985 & 30.73 & 1.28 & 1198.00 & -0.12 & 0.91 & NS \\
\hline & $31-40$ & 215 & 30.75 & 1.41 & & & & \\
\hline Mouth Width & $21-30$ & 985 & 52.89 & 1.79 & 1198.00 & -2.51 & 0.01 & $\mathbf{S}$ \\
\hline & $31-40$ & 215 & 53.23 & 1.88 & & & & \\
\hline Height of Calvaria & $21-30$ & 985 & 38.51 & 2.60 & 1198.00 & 0.61 & 0.54 & NS \\
\hline & $31-40$ & 215 & 38.39 & 2.64 & & & & \\
\hline Lower Nasal & $21-30$ & 985 & 11.44 & 1.97 & 1198.00 & 0.06 & 0.95 & NS \\
\hline & $31-40$ & 215 & 11.43 & 1.97 & & & & \\
\hline Upper Nasal Height & $21-30$ & 985 & 46.56 & 2.22 & 1198.00 & 2.33 & 0.02 & $\mathbf{S}$ \\
\hline & $31-40$ & 215 & 46.17 & 2.36 & & & & \\
\hline Facial Width & $21-30$ & 985 & 132.27 & 2.50 & 1198.00 & 0.41 & 0.68 & NS \\
\hline & $31-40$ & 215 & 132.19 & 2.40 & & & & \\
\hline
\end{tabular}

$\mathrm{S}=$ significant, $\mathrm{NS}=$ not significant

\section{DiscuSSION}

Photogrammetry has been shown to be have certain advantages in the analysis of facial profile considering that measurements are not affected by photographic enlargement, the procedure is noninvasive, and is the commonly used method in investigating pre- and post-operative changes, and provides a permanent record of patients[13]. On comparison to other methods, photogrammetry is inexpensive, utilizes simple tools and offers digital results that are easily evaluated using computer software. Furthermore, there are no dangers or risks associated with it such as exposure to radiation or body contact; it is therefore, ethically more acceptable in developing population norms via population-based studies [14]. This study provides a comparison on the linear craniofacial photogrammetric profile of the three major ethnic groups in Southern Nigeria. The Igbo, Ijaw and Yoruba are negroids who do not have obvious distinct physical features such as height, physique or complexion that could distinguish one from the other. Apart from indices such as tribal marks, accent and mode of dressing, it is difficult to tell if one is Igbo, Yoruba or Ijaw by mere looks. When compared to those in literature, mean TAFH (124.72 \pm 3.30$)$ was lower than that reported for Japanese-Brazilian descendants (124.06 \pm 3.30$)[15]$. LFH (66.02 \pm 2.59$)$ was lower than that of Japanese-Brazilians $\left(72.49 \pm 5 .{ }^{42)}\right.$ [16]. Mean ICD (35.92 \pm 3.82$)$ was higher than those reported for Egyptians (31.8) and Hungarians (31.7) but was lower 
than that of the Japanese (37.5)[16]. Mean OCD $(105.05 \pm 3.37)$ was higher than that reported for Egyptians (89.0), Hungarians (100.4) and Japanese (103.9). NW (40.76 \pm 2.51$)$ was greater than those of the Japanese (38.2), Egyptians (32.4) and Hungarians (37.7) [16]. The mean EFW (32.74 \pm 1.31$)$ was higher than that of the Japanese (30.7) and Egyptians (31.5) and lower than that of the Hungarians (37.7) [16].

MW (53.95 \pm 1.81$)$ was higher than those reported for Japanese (48.4) and Egyptians (48.3) but lower than that of Hungarians (57) [16]. Mean LNH $(12.44 \pm 1.97)$ was higher than that reported for Indians (10.64 \pm 2.71$)[17]$. The mean UNH $(45.49 \pm 2.25)$ was higher than of Indians (44.43 \pm 3.89$)[17]$. Mean FW $(132.26 \pm 2.48)$ was lower than those of the Japanese (147.2), Egyptians (139.8) and Hungarians (142.1) [16]. Effect of age on anthropometric parameters has been reported [18]. This agrees with our finding as age related changes were observed our study in few linear facial parameters. Differences in physical appearance have contributed to the development of the belief that significant inherited differences distinguish humans along the lines of race and ethnicity [19].

\section{CONCLUSION}

The values obtained from this study though varied with values found in literature but they did not deviate from what could be considered normal. This study will be useful in medicine, anthropometric studies and forensics.

\section{Consent}

It is not applicable.

\section{Competing interests} interests exist.

Authors have declared that no competing

\section{REFERENCES}

1. Forrest T. The Advance of African Capital: The Growth of Nigerian Private Enterprise (illustrated ed.). Edinburgh University Press. 1994: 272.

2. Mwakikagile, G. African Countries: An Introduction with Maps. Pan-African Books: Continental Press. 2006: 86.

3. Williams, L. Nigeria: The Bradt Travel Guide. Bradt Travel Guides. 2008, 32.

4. Bob, C. The Marketing of Rebellion: Insurgents, Media, and International Activism. Cambridge University Press. 2005, 55.

5. Nigeria at CIA World Factbook: "Yoruba 21\%" out of a population of 197.8 million

6. Moore KL, Dalley AF. Clinically Oriented Anatomy, Lippincott and Wilkins, Fourth Edition. 1999: 72-78.
7. Mandall NA, McCord JF, Blinkhorn AS, Worthington HV, O'Brien KD. (Perceived aesthetic impact of malocclusion and oral self-perceptions in 14-15-year-old Asian and Caucasian children in greater Manchester. Eur J Orthod. 2000;22(2):17583.

8. Sahin Saglam AM, Gazileri, U. Analysis of Holdaway soft tissue measurement in children between 9 and 12 years of age. Eur. J. Ortho. 2001; 23:287-294.

9. Krishan K, Kumar R. Determination of stature from cephalo-facial dimensions in a North Indian population. Legal Med. 2007;9(3): 128-133.

10. Arnett GW, Bergman RT. Facial keys toorthodontic diagnosis and treatment planning. Part I. American J. Orthodontic Dentofac. Orthoped. 1993;103:299-312.

11. Bergman RT. Cephalometric soft tissue facialanalysis. Am. J. Dentofac. Orthoped.1999; 116(40):373-389.

12. Park HS, Rhee SC, Kang SR, Lee JH. Harmonized profiloplasty using balanced angular profile analysis. Aesthetic plastic surgery. 2004 Apr 1;28(2):89-97.

13. Sforza C, Ferrario VF. Soft-tissue facial anthropometry in three dimensions: From anatomical landmarks to digital morphology in research, clinics and forensic anthropology. Journal of Anthropo- logical Sciences. 2006;84, 97-124.

14. Ferdousi MA, Al Mamun A, Banu LA, Sudip P. Angular Photogrammetric Analysis of the Facial Profile of the Adult Bangladeshi Garo. Advances in Anthropology. 2013;3(4): 188-192.

15. Vieira FP, Pinzan A, Janson G, Fernandes TMF, Sathler RC, Henriques RP. Facial height in Japanese-Brazilian descendants with normal occlusion. Dental Press Journal of Orthodontics, 2014;19(5).

16. Farkas LG, Katic MJ, Forrest CR. International Anthropometric Study of Facial Morphology. Journal of Craniofacial Surgery. 2005;16(4): 615 46.

17. Jeelani W, Fida, M, Shaikh A. Facial Soft Tissue Analysis among Various Vertical Facial Patterns. Journalof Ayub Medical College Abbottabad. 2016;28(1): 29 - 34 .

18. Lee HJ, Park SJ. Comparison of Korean and Japanese Head and Face Anthropometric Characteristics. Human Biology, 2008;80(3): 313330.

19. Olson S. The Use of Racial, Ethnic \& Ancestral Categories in Human Genetics Research. American Journal of Human Genetics. 2005; 77 (40: 519 532. 